\title{
SYNTHESIS, CRYSTAL STRUCTURE AND MAGNETIC PROPERTIES OF $\left[\mathrm{Cu}(\mathrm{mal})(\mathrm{abpt})\left(\mathrm{H}_{2} \mathrm{O}\right)\right] \cdot 3 / 2 \mathrm{H}_{2} \mathrm{O}$ AND $\left[\mathrm{Cu}_{2}(\mathrm{sq})(\mathrm{abpt})_{2}\right] \cdot 2 \mathrm{H}_{2} \mathrm{O}(\mathrm{mal}=$ malonate, sq $=$ squarate, abpt $=4$-amino-3,5-di-2-pyridyl-4H-1,2,4 triazole $)$
}

\author{
Eno A. Ededet ${ }^{1}$, Godfred A. Ayimele ${ }^{2}$, Zhao-Xi Wang ${ }^{3}$, Paul T. Chongwain ${ }^{2}$, Grace E. Iniama ${ }^{1}$, \\ Offiong E. Offiong ${ }^{1^{*}}$ and Emmanuel N. Nfor ${ }^{2 *}$ \\ ${ }^{1}$ Department of Pure and Applied Chemistry, University of Calabar, PMB 1115, Calabar, CRS, \\ Nigeria \\ ${ }^{2}$ Department of Chemistry, University of Buea, P.O. Box 63, Buea, SWR, Cameroon \\ ${ }^{3}$ Department of Chemistry, College of Science, Shanghai University, Shanghai 200444, P.R. \\ China
}

(Received January 11, 2010; revised November 10, 2010)

\begin{abstract}
Two new mixed-ligand complexes of formula $\left[\mathrm{Cu}(\mathrm{mal})(\mathrm{abpt})\left(\mathrm{H}_{2} \mathrm{O}\right)\right] \cdot 3 / 2 \mathrm{H}_{2} \mathrm{O}$ (1) and $\left[\mathrm{Cu}_{2}(\mathrm{sq})(\mathrm{abpt})_{2}\right] \cdot 2 \mathrm{H}_{2} \mathrm{O}(\mathbf{2})$ [mal = malonate, abpt = 4-amino-3,5-di-2-pyridyl-4H-1,2,4 triazole and sq = squarate], have been prepared and characterized by X-ray crystal structure determination and magnetic studies. Complex 1 crystallizes in the monoclinic system, space group C2/c, with $\mathrm{a}=14.0086(2) \AA, \mathrm{b}=10.0980(2) \AA, \mathrm{c}=25.630(4)$ $\AA ; \beta=97.5900(10)^{\circ}$, and $Z=8$. Complex 2 crystallizes in the triclinic system, space group P-1 with $\mathrm{a}=$ 7.5696(15) $\mathrm{A}, \mathrm{b}=8.4697(17) \AA, \mathrm{c}=11.049(2) \AA ; \beta=93.00(3)^{\circ}, \alpha=96.98(3), \gamma=90.111(3)$ and $\mathrm{Z}=1$. Complex 1 consist of a neutral mononuclear $\left[\mathrm{Cu}(\mathrm{mal})(\mathrm{abpt})\left(\mathrm{H}_{2} \mathrm{O}\right)\right]$ unit and water molecule of crystallization in a distorted square pyramidal coordination sphere, while complex $\mathbf{2}$ is viewed as being made up of $\left[\mathrm{Cu}(\mathrm{sq})(\mathrm{abpt})_{2}\right]$ units with the squarato ligand bridging the two copper(II) cations. Variable temperature magnetic behaviour of the complexes reveals the existence of weak antiferromagnetic interaction for complex $\mathbf{1}$ and weak ferromagnetic intrachain interaction for complex 2 .
\end{abstract}

KEY WORDS: Copper(II) complexes, Mixed-ligand, Magnetic properties, Malonate, Squarate, 4-Amino-3,5-di2-pyridyl-4H-1,2,4 triazole

\section{INTRODUCTION}

There has been an increasing interest in metal-organic hybrid materials containing paramagnetic metal ions exhibiting extended open structures due to their wide application in separation technology as well as in the field of molecular magnetism and material chemistry [1-6]. The most commonly used strategy to obtain these extended structures is to employ appropriate bridging ligands that are capable of binding to several metal centers through direct bond formation. Much of the current effort on such extended hybrid metal organic complexes is directed towards synthesizing interesting frameworks using polycarboxylates [7-12] due to thermal stability. These polycarboxylates may exhibit versatile coupling to mediate magnetic interactions owing to their different coordination modes, i.e. syn-syn, anti-syn and anti-anti, etc., accomplishing the transmission of magnetic coupling to different degrees [9].

$1,2,4$-Triazole and, in particular, its derivatives are very interesting bridging ligands and these ligands could provide a 1,2-bridging form; in addition 4-unsubstituted 1,2,4-triazole also has 2,4-bridging fashion which is similar to the 1,3-imidazolate bridging found in enzyme [13].

In this paper, we report the synthesis, single crystal X-ray diffraction analysis and variable temperature (2-300 k) magnetic behaviour of two new mixed-ligand copper(II) complexes using malonate and 4-amino-3,5-di-2-pyridyl-4H-1,2,4-triazole for complex 1 and 4-amino-3,5-di-2pyridyl-4H-1,2,4-triazole and squarate for complex 2 .

*Corresponding author. E-mail: nforemman@gmail.com 


\section{EXPERIMENTAL}

\section{Materials and physical measurements}

All reagents were of AR grade and were used without purification. Elemental analysis for $\mathrm{C}, \mathrm{H}$ and $\mathrm{N}$ were performed on Perkin-Elmer $240 \mathrm{C}$ analyzer (Japan). IR Spectra were obtained for KBr pellets on a Nicolet 170SX FT-IR Spectrophotometer (Japan) in the $400-4000 \mathrm{~cm}^{-1}$ region. Variable-temperature magnetic susceptibility and field dependence of magnetization were performed on a Quantum Design MPMSXL-5 SQUID system (USA).

The experimental susceptibilities were corrected for the dimagnetism of the constituent atoms (Pascal's tables) [1].

\section{Synthesis of $\left[\mathrm{Cu}(\mathrm{mal})(\mathrm{abpt})\left(\mathrm{H}_{2} \mathrm{O}\right)\right] .3 / 2 \mathrm{H}_{2} \mathrm{O}(\mathbf{1})$}

Solid copper(II) basic carbonate (221 mg, $1 \mathrm{mmol}$ ) was added to an aqueous solution (20 mL) of malonic acid (208 mg, $2 \mathrm{mmol}$ ) under continuous stirring. The suspension was heated at 50$60{ }^{\circ} \mathrm{C}$ until a blue solution was obtained. This solution was filtered and mixed with a methanolic solution (30 mL) of 4-amino-3,5-di-2-pyridyl-4H-1,2,4-triazole (112 mg, $0.5 \mathrm{mmol})$ stirred for $20 \mathrm{~min}$. The resulting solution was filtered and the filtrate allowed to crystallize at room temperature by slow evaporation. Single crystals of the complex suitable for X-ray diffraction analysis were obtained within one week. Yield 86\%. Anal. calcd. for 1: C, 39.34; H, 3.96; N, 18.35. Found: C, 40.95; H, 3.67; N, 19.01\%. Main IR absorption band $\left(\mathrm{KBr}, \mathrm{cm}^{-1}\right) 3387,3260$, $1589,1433$.

\section{Synthesis of $\left[\mathrm{Cu}\left(\mathrm{C}_{12} \mathrm{~N}_{6} \mathrm{H}_{10}\right)\left(\mathrm{C}_{4} \mathrm{O}_{4}\right)\left(\mathrm{H}_{2} \mathrm{O}\right)\right] \cdot 2 \mathrm{H}_{2} \mathrm{O}(2)$}

To a solution of 4-amino-3,5-di-2-pyridyl-4H-1,2,4-triazole (238 mg, $1 \mathrm{mmol})$ in methanol (20 $\mathrm{mL}$ ) was added a water/methanol (1:1) solution $(40 \mathrm{~mL})$ of copper(II) nitrate trihydrate, $\mathrm{Cu}\left(\mathrm{NO}_{3}\right)_{2} \cdot 3 \mathrm{H}_{2} \mathrm{O}(116 \mathrm{mg}, 0.5 \mathrm{mmol})$. The resulting blue solution was mixed with a hot solution of squaric acid dilithium salt $(126 \mathrm{mg}, 1 \mathrm{mmol})$ in water $(20 \mathrm{~mL})$. The final solution was filtered and allowed to evaporate for a week at room temperature, giving dark brown crystals of complex suitable for X-ray diffractionstudies. Yield 80\%. Anal. calcd. for 2: C, 41.07; H, 3.45; N, 17.96. Found: C, 41.19; H, 3.54; N, 17.69\%. Main IR absorption band $\left(\mathrm{KBr}, \mathrm{cm}^{-1}\right) 3469$, 3282, 1463, 1060.

$X$-ray crystallography

Crystal structure determination by X-ray diffraction was performed on a Bruker Nonius KappaCCD diffractometer (UK) equipped with a normal focus of $24 \mathrm{~kW}$ sealed tube X-ray source [Mo K $\alpha$ radiation, $\alpha=0.7103 \AA$ ] operating at $50 \mathrm{kV}$ and $40 \mathrm{~mA}$. A hemisphere of intensity data was collected in 2202 frames with $\omega$ scans (width of 0.30 and exposure time of 10 sec per frame) in the $\theta$ range of 1.00 to $27.48^{\circ}$. The total data collected were reduced using SCALEPACK program and the orientation matrix along with the detector and the cell parameters were refined for every 50 frames on all measured reflections. The structures were solved by SIR92 which readily revealed the positions of the heavy atoms $[\mathrm{Cu}, \mathrm{O}]$ and enabled the location of other non-hydrogen positions from the different Fourier maps. All the hydrogen positions were found in the different Fourier maps. For final refinement, hydrogen atom were placed geometrically and held in the riding mode. The last cycles of refinement included atomic positions, anisotropic thermal parameters for non-hydrogen atoms and isotropic parameters for all hydrogen atoms. 
Full matrix least-squares on $\left[\mathrm{F}^{2}\right]$ was done using SHELXL-97 program included in the WINGX package of programs. All crystallographic data are summarized in Table 1. The final geometrical calculations and graphical manipulations were carried out with PARST-97 and PLATON programs. Crystallographic data for the structural analysis have been deposited with the Cambridge Crystallographic Data centre CCDC No 745192 for compound 1 and CCDC No 745193 for compound 2. Copies of this information may be obtained free of charge from The Director, CCDC, 12 Union Road, Cambridge, CB2 IEZ, UK (Fax: +44-1223-336033; e-mail: deposit@ccdc.cam.ac.uk).

Table 1. Crystal data and structure refinement for complexes $\mathbf{1}$ and $\mathbf{2}$.

\begin{tabular}{|c|c|c|}
\hline Compound & 1 & 2 \\
\hline Empirical formula & $\mathrm{C}_{15} \mathrm{H}_{17} \mathrm{CuN}_{6} \mathrm{O}_{6.50}$ & $\mathrm{C}_{28} \mathrm{H}_{24} \mathrm{Cu}_{2} \mathrm{~N}_{12} \mathrm{O}_{6}$ \\
\hline FW & 448.89 & 688.13 \\
\hline $\mathrm{T}(\mathrm{K})$ & 293(2) K & 293(2) K \\
\hline Space group & $\mathrm{C} 2 / \mathrm{c}$ & P-1 \\
\hline Wavelength $(\AA)$ & 0.71073 & 0.71073 \\
\hline Crystal system & Monoclinic & Triclinic \\
\hline \multicolumn{3}{|l|}{ Unit cell dimensions } \\
\hline $\mathrm{a}(\AA)$ & $14.0086(2)$ & $7.5696(15)$ \\
\hline b ( & $10.0982(2)$ & $8.4697(17)$ \\
\hline$c(\AA)$ & $25.6303(4)$ & $11.049(2)$ \\
\hline$\alpha(\operatorname{deg})$ & 90 & $96.98(3)$ \\
\hline$\beta$ (deg) & $97.5900(10)$ & $93.00(3)$ \\
\hline$\gamma(\mathrm{deg})$ & 90 & $90.111(3)$ \\
\hline$V\left(\AA^{3}\right)$ & $3593.87(10)$ & $702.1(2)$ \\
\hline $\mathrm{Z}$ & 8 & 1 \\
\hline $\mathrm{D}_{\mathrm{c}}\left(\mathrm{Mg} / \mathrm{m}^{3}\right)$ & 1.659 & 1.627 \\
\hline$\mu\left(\mathrm{mm}^{-1}\right)$ & 1.267 & 0.847 \\
\hline$F(000)$ & 1840 & 353.0 \\
\hline Crystal size $\left(\mathrm{mm}^{3}\right)$ & $0.18 \times 0.20 \times 0.15$ & $0.15 \times 0.15 \times 0.30$ \\
\hline$\theta$ range $(\mathrm{deg})$ & $1.60-27.48$ & $1.86-27.49$ \\
\hline Index range $(\mathrm{h}, \mathrm{k}, \mathrm{l})$ & $-17 / 17,-13 / 13,-33 / 33$ & $-9 / 9,-10 / 10,-14 / 14$ \\
\hline Reflection collected & 21174 & 21943 \\
\hline Independent reflections $\left(\mathrm{R}_{\text {int }}\right)$ & $4080(0.0568)$ & $3181(0.0445)$ \\
\hline Absorption correction & None & None \\
\hline Data/restraints/parameter Goodness-of-fit on $\mathrm{F}^{2}$ & $4080 / 0 / 292$ & $3181 / 0 / 502$ \\
\hline \multirow[t]{3}{*}{ Final $R$ indices $[\mathrm{I}>2 \sigma>(\mathrm{I})]$} & 1.110 & 1.199 \\
\hline & $\mathrm{R} 1=0.0362$ & $\mathrm{R} 1=0.0678$ \\
\hline & $\mathrm{wR} 2=0.1088$ & $\mathrm{wR} 2=0.1492$ \\
\hline
\end{tabular}

Magnetic susceptibility measurements

The magnetic susceptibilities on powder samples were carried out with a Quantum Design MPMS-XL SQUID magnetometer (USA) in the 1.8-300 K range. The applied magnetic field was $2 \mathrm{kG}$, and the data were corrected for diamagnetism using Pascal's constants and the temperature-independent paramagnetism estimated at $60 \times 10^{-6} \mathrm{emu} / \mathrm{mol} \mathrm{per} \mathrm{Cu}(\mathrm{II})$ ion.

\section{RESULTS AND DISCUSSION}

The coordination environment of the $\mathrm{Cu}$ (II) ion, with atom numbering scheme of the complex $\mathbf{1}$ is shown in Figure 1. The $\mathrm{Cu}$ (II) ion displays a distorted square pyramidal environment with two chelated nitrogen atoms $(\mathrm{N} 2, \mathrm{~N} 3)$ of abpt, two oxygen atoms $(\mathrm{O} 1, \mathrm{O} 4)$ of the malonate ligand 
and an oxygen atom (O5) of the coordinated water molecule. The potentially bis bidentate abpt ligand acting as a bidentated one is coordinated to the copper(II) by one pyridyl and one triazole nitrogen atoms. The three remaining position in the $\left[\mathrm{CuN}_{2} \mathrm{O}_{3}\right]$ core are occupied by the oxygen atoms of the malonate ligand and water. The $\mathrm{Cu}-\mathrm{N}(1)$ (pyridine) $(2.055(2) \AA)$ is significantly longer than the $\mathrm{Cu}-\mathrm{N} 2$ (triazole) (1.999(19) $\AA$ ). This inequivalence in the metal ${ }^{\mathrm{II}}$ - N distances with the abpt ligand has earlier been observed for numerous metal complexes [14]. Thus the $\left[\mathrm{CuN}_{2} \mathrm{O}_{3}\right]$ in the $\left[\mathrm{Cu}\right.$ (mal) $\left.(\mathrm{abpt})\left(\mathrm{H}_{2} \mathrm{O}\right)\right]$ square pyramidal environment is distorted with geometric $\tau$ value of 0.16 . This elongation can be interpreted as a pseudo Jahn-Teller distortion.

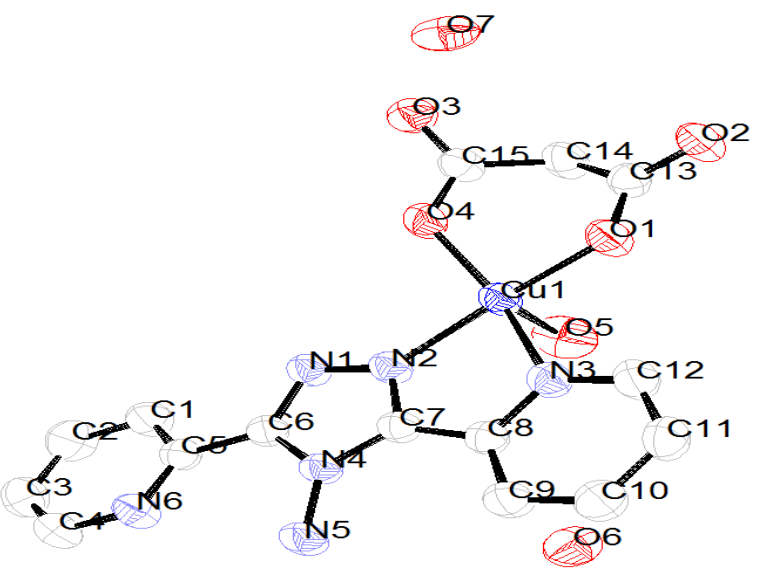

Figure 1. ORTEP view of $\left[\mathrm{Cu}(\mathrm{mal})(\mathrm{abpt})\left(\mathrm{H}_{2} \mathrm{O}\right)\right] \cdot 3 / 2 \mathrm{H}_{2} \mathrm{O}$ with atomic labelling. The displacement ellipsoids are drawn at $50 \%$ probability.

The selected bond lengths and bond angles of complex $\mathbf{1}$ are listed in Table 2. The average value of the $\mathrm{Cu}-\mathrm{O}$ (mal) bond length in the complex lies within the range observed for other malonate-containing copper(II) complexes [15-17]. The malonate adopts a bidentate coordination mode and exhibits a boat conformation in which only the methylene group is significantly shifted out of the chelate ring plane. The value of the angle subtended by the abpt at the metal atom is far from the ideal value of $90^{\circ}\left[\mathrm{N} 3-\mathrm{Cu} 1-\mathrm{N} 2=79.59(8)^{\circ}\right]$ because of the geometrical constraints of abpt [18]. The copper atom is displaced by 0.231 (3) A from the mean basal plane towards the apical position. The configuration of the abpt ligand in the $\left[\mathrm{Cu}(\mathrm{mal})(\mathrm{abpt})\left(\mathrm{H}_{2} \mathrm{O}\right)\right]$ complex is similar to that observed in other mononuclear abpt compounds [19]. The nitrogen atom of the non-coordinated pyridyl group is in the position appropriate to form an intramolecular hydrogen bond with the amino group, i.e., N5-H...N6 (2.876(3) $\AA$ ) [14]. The dihedral angle between the mean planes of the coordinated pyridine and triazole rings is $1.17(2)^{\circ}$, while that between the non-coordinated pyridine and triazole rings is $12.49(2)^{\circ}$ indicating a minimal deviation from true planarity. Bond distances and in plane angles of the triazole and the coordinating pyridyl group are similar to those observed for the $\mathrm{Fe}$ (II) spin-crossover in the $\left[\mathrm{Fe}(\mathrm{abpt})_{2}(\mathrm{NCX})_{2}\right](\mathrm{X}=\mathrm{S}, \mathrm{Se})$ system [19]. The observed values of the angles around the exocyclic $\mathrm{C}-\mathrm{C}$ bonds, which on one side connect the triazole ring to the non-coordinating pyridyl group and on the other side to the coordinating group $[\mathrm{N}(2)-\mathrm{C}(7)-\mathrm{C}(8)$ $\left.=119.3(2), \mathrm{N}(1)-\mathrm{C}(6)-\mathrm{C}(5)=124.5(2)^{\circ}\right]$, and $\mathrm{C}(7)-\mathrm{C}(8)-\mathrm{N}(3)\left[112.4(4)^{\circ}\right]$ are similar to those observed in $\mathrm{Fe}(\mathrm{II})$ complex [20]. The dihedral angles between the equatorial plane at $\mathrm{Cu}(1)$ and those of the $\mathrm{O}(1) \mathrm{C}(13) \mathrm{O}(2)$ and $\mathrm{O}(4) \mathrm{C}(15) \mathrm{O}(3)$ carboxylates are 18.65(2) and 28.82(2) ${ }^{\circ}$. These 
values are very close to those reported for other copper(II) complexes with bidentate malonate $[16,21-22]$. The molecular units are linked by hydrogen bonds in which the nitrogen $N(5)$ from the amino group is hydrogen bonded to the non-coordinating pyridyl nitrogen $\mathrm{N}(6)$, pulling the non-coordinating pyridyl ring into a six-member ring.

Table 2. Selected bond lengths $[\AA ̊]$ and bond angles $\left[{ }^{\circ}\right]$ for aqua-4-amino-3,5-di-2pyridyl-4H-1,2,4triazole-malonatocopper(II) hydrate $\left[\mathrm{Cu}(\mathrm{mal})(\mathrm{abpt})\left(\mathrm{H}_{2} \mathrm{O}\right)\right] \cdot 3 / 2 \mathrm{H}_{2} \mathrm{O}$.

\begin{tabular}{|l|l|}
\hline Bond lengths & {$[\AA]$} \\
\hline $\mathrm{Cu}(1)-\mathrm{O}(4)$ & $1.932(18)$ \\
\hline $\mathrm{Cu}(1)-\mathrm{O}(1)$ & $1.932(17)$ \\
\hline $\mathrm{Cu}(1)-\mathrm{N}(2) \# 1$ & $1.999(19)$ \\
\hline $\mathrm{Cu}(1)-\mathrm{N}(3)$ & $2.055(2)$ \\
\hline $\mathrm{Cu}(1)-\mathrm{O}(5)$ & $2.244(2)$ \\
\hline $\mathrm{Bond}$ angles & {$\left[^{\circ}\right]$} \\
\hline $\mathrm{O}(4)-\mathrm{Cu}(1)-\mathrm{O}(1)$ & $93.10(8)$ \\
\hline $\mathrm{O}(4)-\mathrm{Cu}(1)-\mathrm{N}(2)$ & $93.56(8)$ \\
\hline $\mathrm{O}(1)-\mathrm{Cu}(1)-\mathrm{N}(2)$ & $168.14(8)$ \\
\hline $\mathrm{O}(4)-\mathrm{Cu}(1)-\mathrm{N}(3)$ & $158.47(9)$ \\
\hline $\mathrm{O}(1)-\mathrm{Cu}(1)-\mathrm{N}(3)$ & $90.68(8)$ \\
\hline $\mathrm{N}(2)-\mathrm{Cu}(1)-\mathrm{N}(3) \# 1$ & $79.59(8)$ \\
\hline $\mathrm{O}(4)-\mathrm{Cu}(1)-\mathrm{O}(5)$ & $101.78(10)$ \\
\hline $\mathrm{O}(1)-\mathrm{Cu}(1)-\mathrm{O}(5)$ & $94.15(9)$ \\
\hline $\mathrm{N}(2)-\mathrm{Cu}(1)-\mathrm{O}(5) \# 2$ & $94.09(9)$ \\
\hline $\mathrm{N}(3)-\mathrm{Cu}(1)-\mathrm{O}(5)$ & $99.08(10)$ \\
\hline
\end{tabular}

Table 3. Selected bond lengths $[\AA]$ and bond angles $\left[{ }^{\circ}\right]$ for complex aqua-(4-amino-3,5-di-2-pyridyl-4H1,2,4-triazole-squarato)copper(II) dihydrate.

\begin{tabular}{|l|l|}
\hline Bond lengths & {$[\AA]$} \\
\hline & \\
\hline $\mathrm{Cu}(1 \mathrm{~b})-\mathrm{N}(1 \mathrm{~b}) \# 1$ & $2.042(6)$ \\
\hline $\mathrm{Cu}(1 \mathrm{~b})-\mathrm{N}(2 \mathrm{~b})$ & $1.994(6)$ \\
\hline $\mathrm{Cu}(1 \mathrm{~b})-\mathrm{O}(1 \mathrm{~b}) \# 1$ & $2.495(6)$ \\
\hline $\mathrm{Cu}(1)-\mathrm{N}(1) \# 2$ & $2.042(6)$ \\
\hline $\mathrm{Cu}(1)-\mathrm{N}(2)$ & $1.994(6)$ \\
\hline $\mathrm{Bond}$ angles & {$\left[^{\circ}\right]$} \\
\hline $\mathrm{N}(1 \mathrm{~b})-\mathrm{Cu}(1 \mathrm{~b})-\mathrm{N}(2 \mathrm{~b}) \# 1$ & $80.55(13)$ \\
\hline $\mathrm{O}(1 \mathrm{~b})-\mathrm{Cu}(1 \mathrm{~b})-\mathrm{N}(2 \mathrm{~b})$ & $91.30(10)$ \\
\hline $\mathrm{N}(1) \# 1-\mathrm{Cu}(1 \mathrm{~b})-\mathrm{O}(1 \mathrm{~b})$ & $94.25(10)$ \\
\hline $\mathrm{N}(1)-\mathrm{Cu}(1)-\mathrm{N}(2) \# 1$ & $80.55(10)$ \\
\hline $\mathrm{O}(1 \mathrm{a}) \# 1-\mathrm{Cu}(1)-\mathrm{N}(2 \mathrm{a}) \# 1$ & $91.30(10)$ \\
\hline $\mathrm{N}(1)-\mathrm{Cu}(1)-\mathrm{O}(1 \mathrm{a}) \# 1$ & $94.25(3)$ \\
\hline
\end{tabular}

Symmetry transformations used to generate equivalent atoms: \#1 x,-y+1/2, z+1/2 \#2 x,-y+1/2, z-1/2.

The structure of the complex 2 with atom numbering scheme (Figure 2) can be viewed as being made up of isolated $[\mathrm{Cu}(\mathrm{abpt}) 2(\mathrm{Sq})]$ units, in which two metal cations are bridged by squarato ligand. The squarato group bridges the copper(II) ions, while abpt acts as abidentate ligand. The $\mathrm{Cu}$ (II) is bonded to two abpt nitrogen atoms [2.0042(6) and 1.994(6) $\AA$ for $\mathrm{Cu}(1)$ pyridine $\mathrm{N}(1)$ and $\mathrm{Cu}(1)$-triazoleN(2)], respectively. The two crystallographically independent copper(II) ions are pentacoordinated within a distorted square based pyramid. In the polymeric unit, the copper-copper distance is $9.574 \AA$ 


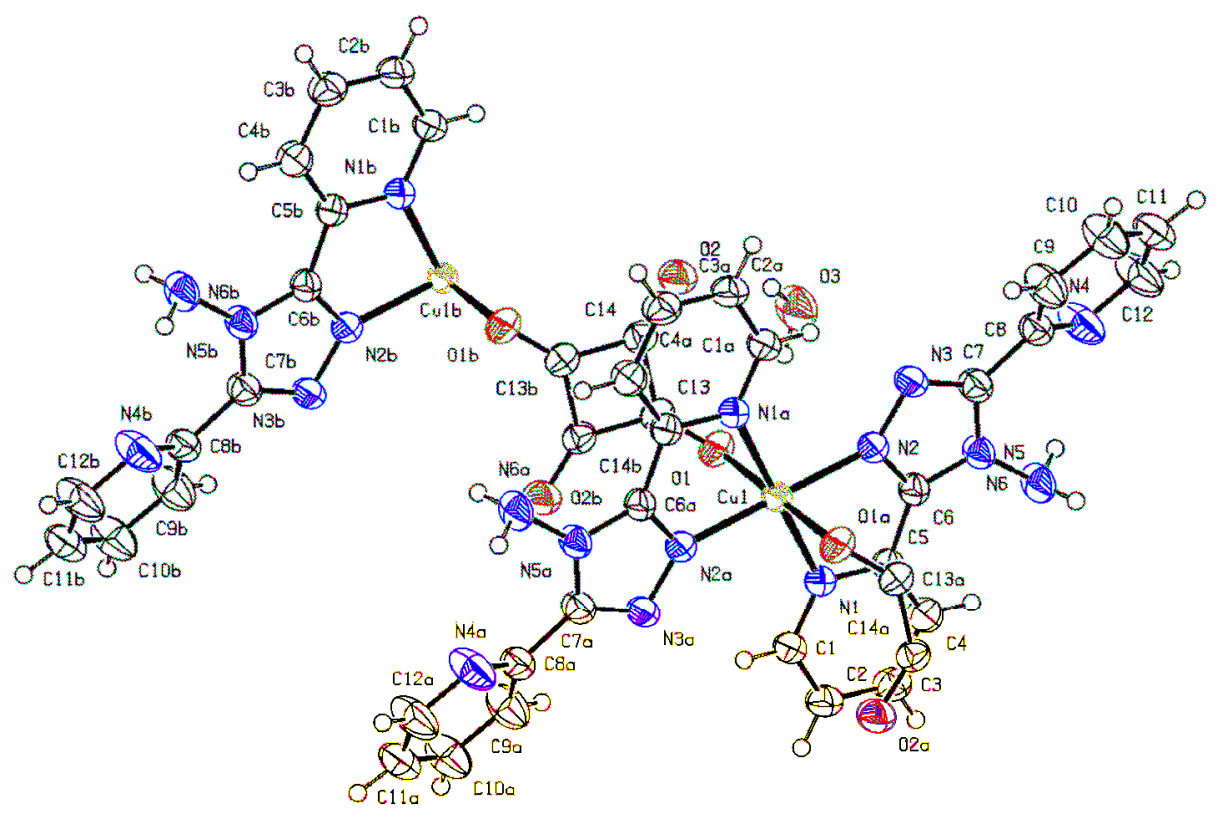

Figure 2. ORTEP drawing of the polymeric unit of complex 2 showing the atom-labelling scheme. The displacement ellipsoid is drawn at $50 \%$ probability.

The axial positions are occupied by squarato oxygen atoms. The $\mathrm{Cu}-\mathrm{N}$ and $\mathrm{Cu}-\mathrm{O}$ bond distances in the basal plane for $\mathrm{Cu}(1)$ and $\mathrm{Cu}(2)$ ranges from $2.042 \AA$ to $2.495 \AA$ which are in agreements with previously reported values for several compounds in the $\mathrm{Cu}$-abpt and $\mathrm{Cu}$ squarato systems [23-24]. On the other hand, the longer $\mathrm{Cu}-\mathrm{O}$ (squarato) distances $(\mathrm{Cu}(1)-\mathrm{O}=$ $2.495 \AA$ and $\mathrm{Cu}(2)-\mathrm{O}=2.495 \AA$ are very close to those reported for other $\mathrm{Cu}(\mathrm{II})$ complexes involving $\mathrm{O}$ (squarato) atoms in the apical position [25-26]. The angles around copper atoms in the basal planes vary from $80.55^{\circ}$ to $99.45^{\circ}$.

\section{Magnetic properties}

The temperature dependence of magnetic susceptibility of complex $\mathbf{1}$ in the form of $\chi_{\mathrm{M}} \mathrm{T}$ versus $\mathrm{T}$ plots is shown in Figure 3. At room temperature, the $\chi_{\mathrm{M}} \mathrm{T}$ value is $0.46 \mathrm{emu} \mathrm{K} \mathrm{mol}^{-1}$. As the temperature decreases, the $\chi_{\mathrm{M}} \mathrm{T}$ value remains nearly unchanged and finally reaches a value of $0.40 \mathrm{emu} \mathrm{K} \mathrm{mol}{ }^{-1}$ at $25 \mathrm{~K}$. The values are slightly above the value predicted for an isolated $\mathrm{S}=$ $1 / 2$ spin with $\mathrm{g}=2.0\left(0.37 \mathrm{~cm}^{3} \mathrm{~mol}^{-1} \mathrm{~K}\right)$. This remains practically unchanged down to $25 \mathrm{~K}$ below which temperature, a slight increased is observed. This magnetic behaviour indicates the existence of a very weak antiferromagnetic interaction between $\mathrm{Cu}$ (II) ions.

Plot of the magnetic susceptibility of the complex 2 in the form of $\chi_{M} T$ versus $T$ plots $\left[\chi_{M}\right.$ being the magnetic susceptibility per $\mathrm{Cu}(\mathrm{II})$ ion] is shown in Figure 4. At room temperature the $\chi_{\mathrm{M}} \mathrm{T}$ value is $0.369 \mathrm{emu} \mathrm{K} \mathrm{mol}^{-1}$ which is close to the value predicted for an isolated $\mathrm{S}=1 / 2 \mathrm{spin}$ with $\mathrm{g}=2.0\left(0.37 \mathrm{~cm}^{3} \mathrm{~mol}^{-1} \mathrm{~K}\right)$, and smoothly increases to a value of $0.45 \mathrm{emu} \mathrm{K} \mathrm{mol}^{-1}$ at $2 \mathrm{~K}$. This is attributed to weak ferromagnetic intrachain interaction mediated by the bridged ligand [25]. 


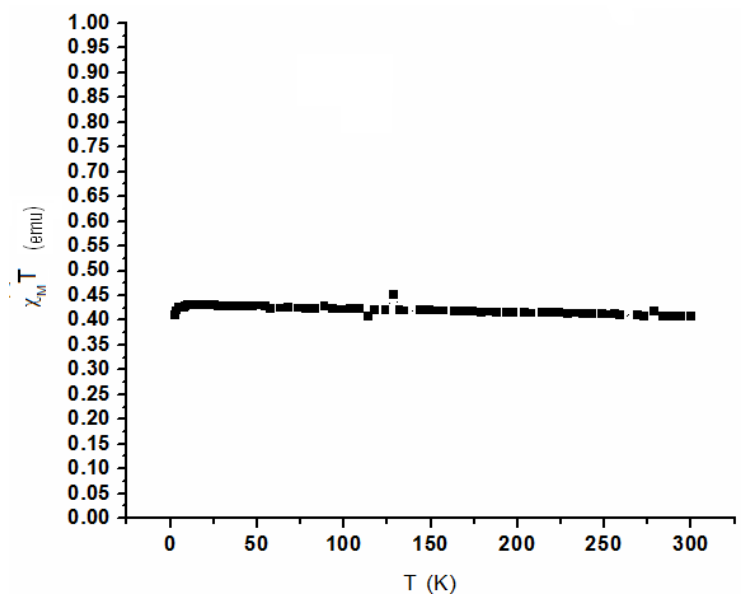

Figure 3. Magnetic susceptibility curve for aqua-4-amino-3,5-di-2-pyridyl-4H-1,2,4-triazolemalonatocopper(II) hydrate $\left[\mathrm{Cu}(\mathrm{mal})(\mathrm{abpt})\left(\mathrm{H}_{2} \mathrm{O}\right)\right] .3 / 2 \mathrm{H}_{2} \mathrm{O}$.

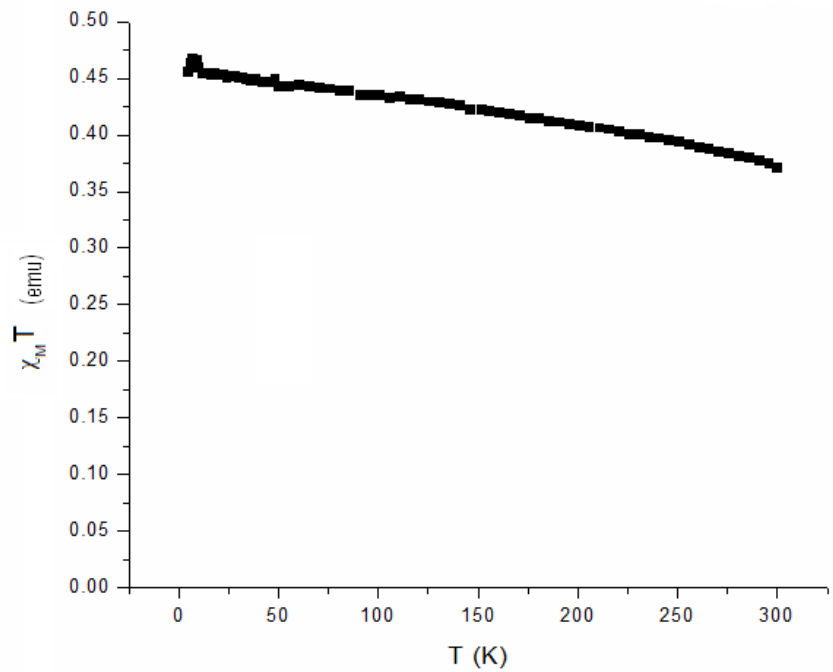

Figure 4. Magnetic susceptibility curve for aqua-(4-amino-3,5-di-2-pyridyl-4H-1,2,4-triazolesquarato) copper(II) dihydrate $\left.\left[\mathrm{Cu}(\mathrm{sq})(\mathrm{abpt})_{2}\right)\right] \cdot 2 \mathrm{H}_{2} \mathrm{O}$.

\section{CONCLUSIONS}

In the present paper, we have discussed the synthesis, crystal structures, and magnetic behaviour in the temperature range of $2-300 \mathrm{~K}$ of two metal-organic based polymers of $\mathrm{Cu}$ using similar ligands. In complex 1, abpt and malonate behaves as bidentate ligands, whereas in complex $\mathbf{2}$, the abpt equally behaves as a bidentate ligand, while the squarato ligand bridges the two copper centers and lattice water remains uncoordinated. Variable temperature magnetic studies of the two complexes shows the existence of weak antiferromagnetic interaction for complex $\mathbf{1}$ and weak ferromagnetic intrachain mediated by the bridge ligand for complex $\mathbf{2}$.

Bull. Chem. Soc. Ethiop. 2011, 25(1) 


\section{ACKNOWLEDGEMENTS}

EAE thanks the Third World Academy of Science (TWAS) for the support through advanced training fellowship and Prof. Yu Wang of the University of Taiwan for hosting and providing all the laboratory facilities.

\section{REFERENCES}

1. Kahn, O. Molecular Magnetism, VCH Publishers: New York; 1993.

2. Froster, P.M.; Cheetham, A.K. Angew. Chem. Int. Ed. 2002, 41, 457.

3. Barthelet, K.; Marrot, J.; Riou, D.; Ferey, G. Angew. Chem. Int. Ed. 2002, 41, 281.

4. Sun, H-L.; Gao, S.; Ma, B.Q.; Su, G. Inorg. Chem. 2003, 42, 5399.

5. Sun, H-L.; Gao, S.; Ma, B.Q.; Su, G.; Niu, Z-M.; Wang, Z-M. J. Chem. Soc. Dalton Trans. 2000, 4187.

6. Ribas, J.; Escuer, A.; Monfort, M.; Vicente, R.; Cortes, R.; Lezama, L.; Rojo, T. Coord. Chem. Rev. 1999, 193, 1027.

7. Tamaka, H.; Zhong, Z.J.; Matsumoto, N.; Kida, S.; Koikawa, K.; Adiwa, N.; Okawa, H. J. Am. Chem. Soc. 1992, 114, 6974.

8. Mathaniere, C.; Nuttal, C.J.; Carling, S.G.; Day, P. Inorg. Chem. 1996, 35, 1201.

9. Andres, R.; Brissard, M.; Gruselle, M.; Train, C.; Vaissermann, J.; Malezieux, B.; Janet, J.P.; Verdaquer, M. Inorg. Chem. 2001, 40, 4633.

10. Deakin, L.; Ariff, A.H.; Miller, J.S. Inorg. Chem. 1999, 38, 5072.

11. Lo, M-F.S.; Chui, S-Y.S.; Shek, L.Y.; Liu, Z.; Zhang, X.X.; Wen, G.H.; Williams, I.D. J. Am. Chem. Soc. 2000, 122, 6293.

12. Chui, S-Y.S.; Lo, M-F. S.; Charmant, J-P.H.; Orpen, A.G.; Williams, I.D. Science 1999, $238,1148$.

13. Messerschmidt, A.; Ressi, A.; Ladenstein, R.; Haber, R.; Bolognesi, M.; Gatti, G.; Marchesini, A.; Finazzi-Agro, A. J. Mol. Biol. 1989, 206, 513.

14. Garcia-Couceriro, U.; Castillo, O.; Luque, A.; Garcia-Teran, J-P.; Beobide, G.; Roman, P. Eur. J. Inorg. Chem. 2005, 21, 4283.

15. Sanchz, J.; Rodriguez, M.; Ruiz-Perez, C.; Mederos, A.; Lloret, F.; Julve, M. New J. Chem. 2002, 26, 1626.

16. Liu, T.F.; Sun, H-L.; Gao, S.; Zhang, S-W.; Lau, T-C. Inorg. Chem. 2003, 42, 4793.

17. Li, B.; Wang, X.; Zhang, Y.; Gao, S. Inorg. Chim. Acta 2005, 358, 3521.

18. Rodriguez, M.; Sancho, J.; Ruiz-Perez, C.; Lloret, F.; Julve, M. Inorg. Chim. Acta 2001, $326,23$.

19. Molinear, N.; Gaspar, A.B.; Munoz, M.C.; Niel, V.; Cano, J.; Real, J.A. Inorg. Chem. 2001, 40, 3989.

20. Real, J.A.; Gaspar, A.B.; Munoz, M.C. Dalton Transaction 2005, 2066.

21. Liang, M.; Wang, Q.-L.; Yu, L.-H.; Liao, D.-Z.; Jiang, Z.-H.; Yan, S.-P.; Cheng, P. Polyhedron 2004, 23, 2205.

22. Hernandez-Molina, M.; Lorenzo-Luis, P.; Ruiz-Perez, C.; Lopez, T.; Martin, I.R.; Anderson, K.M.; Orpen, A.G.; Bocanegra, E.H.; Lloret, F.; Julve, M.J. Chem. Soc. Dalton Trans. 2002, 3468.

23. Hosien, H.A.; Jaggernauth, H.; Alleyne, B.D.; Zein, S.; Hall, L.A.; Withe, A.J.P.; Williams, D.J. Inorg. Chem. 1999, 38, 3716.

24. Sinditskii, V.P.; Sokol, V.I.; Fogel'zang, A.E.; Dutov, M.D.; Serushkin, V.V.; PoraiKoshits, V.M.; Svetlov, B.S. Russ. J. Inorg. Chem. 1987, 32, 1149.

25. Akhriff, Y.; Server-Carrior, C.; Sancho, A.; Garcia-Lozano, J.; Escriva, E., Soto, L. Inorg. Chem. 2001, 40, 6835.

26. Castro, I.; Faus, J.; Julve, M.; Verdaguer, M.; Monge, A.; Gutierrez-Pueble, E. Inorg. Chim. Acta 1990, 170, 251. 